\title{
杭位置の影響を考慮した群杭の非線形水平地盤ばね簡易評価手法 SIMPLE METHOD FOR MEASUREMENT OF NON-LINEAR LATERAL SOIL SPRING WITH CONSIDERATION OF EFFECT OF PILE ARRANGEMENT
}

\author{
成田修英*1, 金子 治*2, 根本 恒*3, 金井重夫*4, 新井寿昭*5 \\ Nobuhide NARITA, Osamu KANEKO, Hisashi NEMOTO, \\ Shigeo KANAI and Toshiaki ARAI
}

\begin{abstract}
Under lateral loading on a pile group, each pile bears different lateral force depending on its position among the group. This effect of pile position is remarkable in comparison between outer piles and the other. So, the effect appears remarkably in lateral resistance elements at the outside of foundation used for seismic retrofit. The author have studied the pile group effect accounting the pile position. This paper presents a simple method to compute the pile group effect considering the pile arrangement through the 3D-FEM analysis and its comparison with experimental results.
\end{abstract}

Keywords : Group-pile effect, Lateral soil spring, Influence factor, 3D-FEM 群杭効果，地盤ばね，影響係数，3D-FEM

1. はじめに

群杭の水平載荷において, 各杭が負担する水平力は杭の位置によ って異なることが知られており，3 次元弾塑性有限要素解析を用い たシミュレーションも行われている 1) 33)痃ど。杭の位置による負担 水平力の違いの例を図 1 に示寸。同図にあるように, 特に外周部の 杭とそれ以外の杭とで違いが顕著となる。近年, 基礎外周部に水平 抵抗要素を設ける基礎耐震工法 4), 5) が開発されつつあるが，そこで 用いられる水平抵抗要素は位置の違いによる影響を大きく受けると 考えられる。著者らは, 増し杭による基礎耐震補強を想定し, 外周 部に位置する杭の負担水平力を適切に評価することを目的として, 群杭効果の検討を行っている。

塑性領域まで考慮した群杭の水平地盤反力について, 冨永ら 6) 8) は Poulos の群杭理論 9, 10) を現実の群杭に近い条件を設定して修正 し, 模型実験結果と比較して理論值と実測值が良く対応することを 示した。また, 鈴木ら 11) は模型実験結果の回帰分析を行い, 非線形 特性を適切に評価した Winkler ばねを用いることにより（杭の位置 による影響まで含めた）群杭の地盤反力ー変位関係が模擬できるこ とを示している。群杭における水平地盤反力評価の模式図を図 2 に 示す。同図において, Poulos と冨永らの研究は(a)の評価手法を示 したもの, 鈴木らの研究は(a)的な現象が(b)の手法で近似できること を示したものだと言える。

冨永らの理論は，弾性領域の地盤における影響係数の考え方と塑

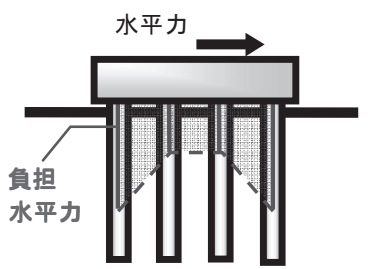

(a) 弹性領域

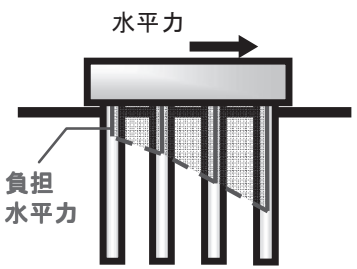

(b) 塑性領域
図 1 群杭の水平力分布の例

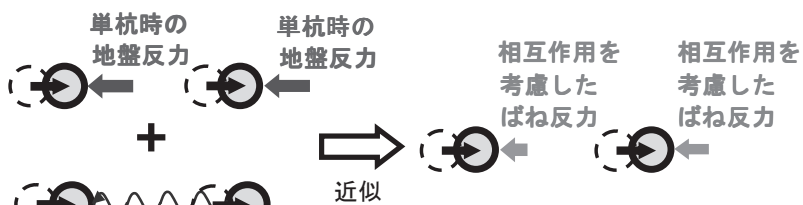

（b）簡易的評価手法

(a) 基本的な考え方

図 2 群杭における水平地盤反力評価の模式図

性領域の地盤における塑性地盤反力の考え方とを組み合わせ，うま く模型実験結果を説明できる群杭のモデルを構築することに成功し ているが，基礎設計の実務で用いるには影響係数の計算がやや煩雑 である。しかしながら，影響係数の評価に関しては簡易な手法とし て Nogami 12) の方法，Dobry ら 13) の方法，土方ら 14)の方法などが

*1 戸田建設技術研究所 研究員 · 工修

*2 戸田建設技術研究所 主管.工修

*3 安藤建設技術研究所 室長. 工学

*4 千代田工営社長室 室長.Ph. D.

*5 西松建設技術研究所 課長代理・工修
Researcher, Technical Research Institute, TODA CORPORATION, M. Eng.

Manager, Technical Research Institute, TODA CORPORATION, M. Eng.

Director, Research Center, ANDO CORPORATION, M. Eng.

Director, Planning Section, CHIYODA GEOTECH CO., LTD., Ph. D.

Manager, Technical Research Institute, NISHIMATSU CONSTRUCTION, M. Eng. 
提案されており，これらの成果を応用することで影響係数評価にか かる計算負荷を低減することが可能だと考えられる。

これらの先行研究に基づき, 本研究では杭位置の影響を考慮した 群杭の水平地盤げね簡易評価手法を示す。

\section{2. 提案手法における群杭効果のモデル}

提案手法では地盤ばねとして双曲線モデルを採用し, 杭の水平地 盤反力を(1)式で表わす。

$$
p=\frac{\xi_{0} k_{h 0} y}{1+\frac{\xi_{0} k_{h o}|y|}{\xi_{y} p_{y}}}
$$

ここに, $p$ : 杭の水平地盤反力, $\xi_{0}$ : 弾性領域における群杭効果に よる地盤ば水の低減係数, $k_{h o}$ : 単杭の初期水平地盤反力係数, $y$ : 杭一地盤間相対変位, $\xi_{y}$ : 塑性領域における群杭効果による地盤ば ねの低減係数, $p_{y}$ : 単杭の塑性地盤反力

(1)式による地盤ばねにおいて弾性領域（初期）の地盤ばねと塑性 領域の地盤反力はそれぞれ(2)，(3)式のようになる。

$$
\begin{aligned}
& \lim _{y \rightarrow 0}\left(\frac{p}{y}\right)=\xi_{0} k_{h 0} \\
& \lim _{y \rightarrow \infty} p=\xi_{y} p_{y}
\end{aligned}
$$

(1)式において $k_{h o} \cdot p_{y}$ は単杭時の既往の方法 15) を用いて決定す ることが可能である。群杭効果は全て $\xi_{0}$ と $\xi_{y}$ の 2 つのパラメータ で考慮する。本手法では簡単のため, $\xi_{0}$ 。 $\xi_{y}$ は全深度で一定とし 杭頭位置での影響係数を基に決定する。

$$
\begin{aligned}
& \xi_{0}=e_{0}^{4 / 3}, \quad \xi_{y}=e_{y}^{4 / 3} \\
& e_{0 i}=\frac{1}{\sum_{j \in A} x_{i j}} \\
& e_{y i}=\frac{1}{\sum_{j \in F i} x_{i j}}
\end{aligned}
$$$$
\xi_{0} \cdot \xi_{y} \text { と影響係数の関係は }(4) \sim(6) \text { 式のように定める。 }
$$

ここに, $e_{0}$ : 弾性領域での群杭係数, $e_{y}$ : 塑性領域での群杭係数, $e_{0 i}$ : 杭 $\mathrm{i}$ に対する $e_{0}, e_{y i}$ : 杭 $\mathrm{i}$ に対する $e_{y}, A$ : 全ての杭の集合, $x_{i j}$ : 杭 $\mathrm{j}$ の杭 $\mathrm{i}$ に対寸る影響係数, $F_{i}$ : 杭 $\mathrm{i}$ よりも前方に位置寸る 杭の集合（真横に位置する杭含む）（また $x_{i j}$ の数值自体は (3) 式と 共通の值を用いる)

（4）式における $4 / 3$ 乗は弾性支承梁の理論における水平地盤反力 係数と杭頭せん断力の関係より定めた。 $e_{0}$ は影響係数の考え方によ り(5)式のように定まる。

$e_{y}$ については塑性領域での群杭効果に対して一つの仮定を置き (6)式により求めることとする。これに関連して, 影響係数の考え方 を図 3 に, 杭の水平地盤反力発生機構を図 4 に示す。図 3 上り弾性 領域においては全ての杭が互いに影響を及ぼしあうが, 図 4 より塑 性領域においては杭の背面側の地盤はほとんど剥離したような状態 になっており背面側の杭からの影響は受けにくくなっていると考え られる。このことから,「塑性領域においては, 杭 i は載荷方向を基 準として前方に位置する杭のみから影響を受ける（後方の杭は無視

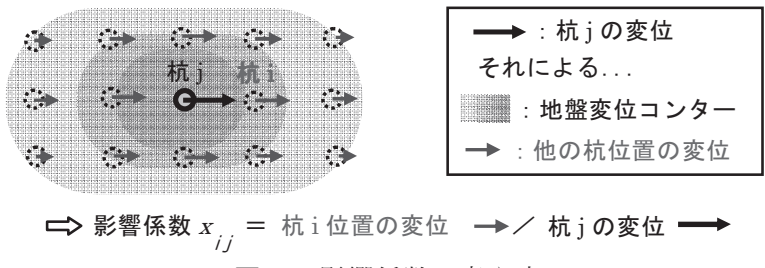

図 3 影響係数の考え方

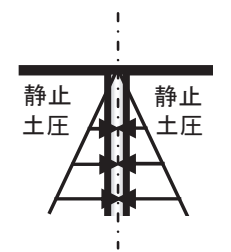

(a) 静止

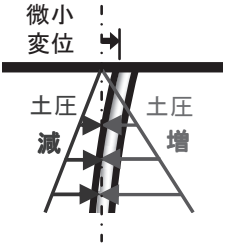

(b) 弾性領域

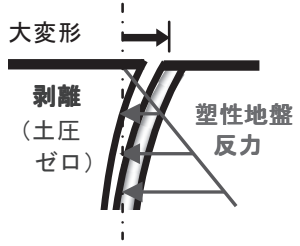

（c）塑性領域
図 4 杭の水平地盤反力発生機構

する)」という条件を仮定し，その仮定の下で影響係数を用いて群杭 係数を定式化したのが(6)式である。

(1)〜 (6) 式によって群杭に含まれる杭の地盤ばねを決定するとき, 影響係数 $x_{i, j}$ が以下の条件を満たせば, 群杭の水平力分布は図 1 の ような傾向（弾性領域において中央で負担が小さく, 塑性領域にお いて前方の杭ほじ負担が大きい）を示す。

条件 1）影響係数は相互作用する杭の杭芯距離の関数であり正の值 をとる（(7) 式

条件 2）杭芯距離が近ければ近いほど影響係数は大きい（(8)式)

$$
\begin{aligned}
& x_{i j}=f\left(r_{i j}\right)>0 \\
& r_{i j}<r_{i k} \Rightarrow f\left(r_{i j}\right)>f\left(r_{i k}\right)
\end{aligned}
$$

ここに, $r_{i j}$ : 杭 $\mathrm{i}-\mathrm{j}$ の杭芯距離, $f\left(r_{i j}\right): r_{i j}$ の関数

これらの条件と $(1) \sim(6)$ 式を用いて評価した群杭の水平力分布の 関係についての説明は付録に記載する。

影響係数については(7),(8)式を満たすのであれば既往のいかなる 手法を用いて計算することが可能である。先に挙げた文献 12$), 13), 14$ の影響係数評価手法はいずれも使用可能である。ただし，外周部の 杭の負担を適切に評価したいという本研究の目的と，これら既往の 手法が想定している使用目的とは整合しない部分があり実用上不都 合を生じる。著者らは, 提案手法のための簡易な影響係数計算法と して以下の $(9) \sim(13)$ 式を提案する。

まず杭 $\mathrm{i}$ と杭 $\mathrm{j}$ を結ぶ直線が載荷方向に対して $\theta_{i j}$ 傾いている場 合の影響係数を(9)式のように近似する ${ }^{13)}$ 。

$$
x_{i j}=f_{x} \cdot \cos ^{2} \theta_{i j}+f_{y} \cdot \sin ^{2} \theta_{i j}
$$

ここに, $f_{x}: \theta_{i j}=0$ の場合の影響係数, $f_{y}: \theta_{i j}=90^{\circ}, 270^{\circ}$ の場 合の影響係数

$f_{x}, f_{y}$ は(10), (11) 式のような近似を考える。

$$
\begin{aligned}
& f_{x}=f\left(r_{i j}, \alpha\right)=\frac{1}{2 \alpha \cdot \overline{r_{i j}}+(1-\alpha)} \\
& f_{y}=f\left(r_{i j}, \beta\right)=\frac{1}{2 \beta \cdot \bar{r}_{i j}+(1-\beta)}
\end{aligned}
$$

ここに, $\alpha, \beta$ : 杭間隔に対する影響係数の感度を表す定数, $\bar{r}_{i j}$ ： 杭 i の杭径で正規化した杭 $\mathrm{i}-\mathrm{j}$ の杭芯距離 $\left(\overline{r_{i j}}=1 / 2\right.$ とする $)$ 定数項 $\alpha, \beta$ は次式により決定する。 


$$
\begin{aligned}
& \alpha=a \cdot\left(\frac{E_{s}}{E_{p}}\right)^{b} \\
& \beta=c \cdot\left(\frac{E_{s}}{E_{p}}\right)^{d}
\end{aligned}
$$

ここに, $a, b, c, d$ : 回帰係数, $E_{s}$ : 地盤の変形係数, $E_{p}$ : 杭の変 形係数

$a, b, c, d$ 具体的な数值の算出は続 $<3$ 章において 3 次元弾性 FEM を用いて行う。

以上, 杭位置の影響を考慮した群杭の水平地盤ばね評価のフロー を図 5 に示す。同図の計算手順は杭本数が少ない場合を除けば計算 機の使用が必須であり, 更なる計算負荷の低減が今後の課題となる。

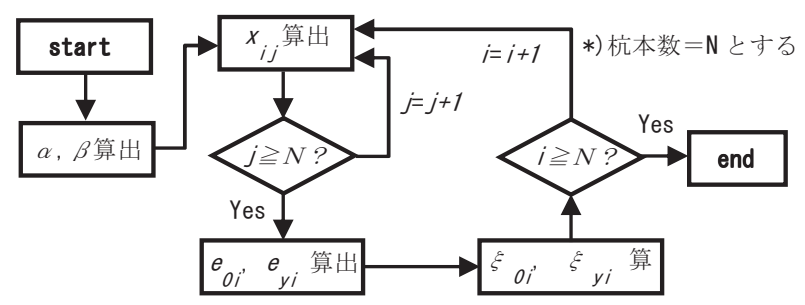

図 5 提案手法による群杭効果評価フロー

\section{3 次元弾性 FEM を用いた群杭効果の回帰分析}

基本解析モデルを図 6 に示す.このモデルを用いた 3 次元弾性 FEM 解析（解析コード CTC 社, SoilPlus ver. 2010)によるパラメータ・ス タディ結果を用いて (12), (13) 式の回帰係数を決定する。

基本解析モデルについてはモデル中央に単杭 (杭径 $1 \mathrm{~m}$, 杭長 20m) をモデル化し, それ以外を単層の地盤要素としている. 側方境界に ついては有限領域でモデルを切り出している影響を小さくするため, 固定境界と自由境界とで計算を行い, 2 つの結果における杭頭せん 断力（強制変位に対する反力）の差が5\%以内であることを確認した 上で, 2 つの結果の平均を解析結果として用いている。

\section{1 回帰係数の決定}

回帰係数決定のための基本解析モデルを用いたパラメータ・スタ ディの諸元と解析結果より決定した回帰係数を表 1 に示す。同表に おける回帰係数決定の手順を以下に記す。

(1) 解析結果を次式に代入し影響係数 $f_{x}, f_{y}$ を決定する。

$$
\begin{gathered}
f_{x}=\frac{u_{s}(\bar{r}, 0)}{u_{p}} \\
f_{y}=\frac{u_{s}(0, \bar{r})}{u_{p}}
\end{gathered}
$$

ここに, $u_{S}(x, y)$ : 杭芯を原点としたときの座標 $(x, y)$ における載荷 方向地表変位, $u_{p}:$ 杭頭変位

(2) 決定した各ケースごとの $f_{x}, f_{y}$ に対し, (10), (11) 式を回帰関数 として最小二乗法で $\alpha, \beta$ を決定寸る。(1), (2)の手順により得た $f_{x}$, $f_{y}$ と回帰曲線を図 7,8 に示寸。同図において解析結果より求めた 值をマーカーで，それに対する回帰曲線をラインで示している。

(3) 決定した $\alpha, \beta$ に対し, (10), (11) 式を回帰関数として最小二乗

\begin{tabular}{|c|c|c|c|c|c|c|c|c|}
\hline \multirow{3}{*}{ case } & \multicolumn{4}{|c|}{ 解析パラメータ } & \multirow{2}{*}{\multicolumn{4}{|c|}{ 回帰係数 }} \\
\hline & \multicolumn{2}{|c|}{ 地盤 } & \multicolumn{2}{|l|}{ 杭 } & & & & \\
\hline & $E_{s}(M P a)$ & $\nu_{\mathrm{s}}$ & $E_{p}(M P a)$ & $\nu_{p}$ & a & $\mathrm{b}$ & $\mathrm{c}$ & d \\
\hline$\overline{D D-1}$ & $\begin{array}{ll}1 \\
\end{array}$ & \multirow{4}{*}{0.30} & \multirow{8}{*}{20,000} & \multirow{8}{*}{0.20} & \multirow{4}{*}{0.78} & \multirow{4}{*}{0.18} & \multirow{4}{*}{1.2} & \multirow{4}{*}{0.16} \\
\hline $\mathrm{D}-2$ & 10 & & & & & & & \\
\hline$D-3$ & 100 & & & & & & & \\
\hline $\mathrm{D}-4$ & 1,000 & & & & & & & \\
\hline $\mathrm{S}-1$ & 1 & \multirow{4}{*}{0.45} & & & \multirow{4}{*}{0.63} & \multirow{4}{*}{0.17} & \multirow{4}{*}{1.3} & \multirow{4}{*}{0.16} \\
\hline $\mathrm{S}-2$ & 10 & & & & & & & \\
\hline$S-3$ & 100 & & & & & & & \\
\hline$S-4$ & 1,000 & & & & & & & \\
\hline
\end{tabular}

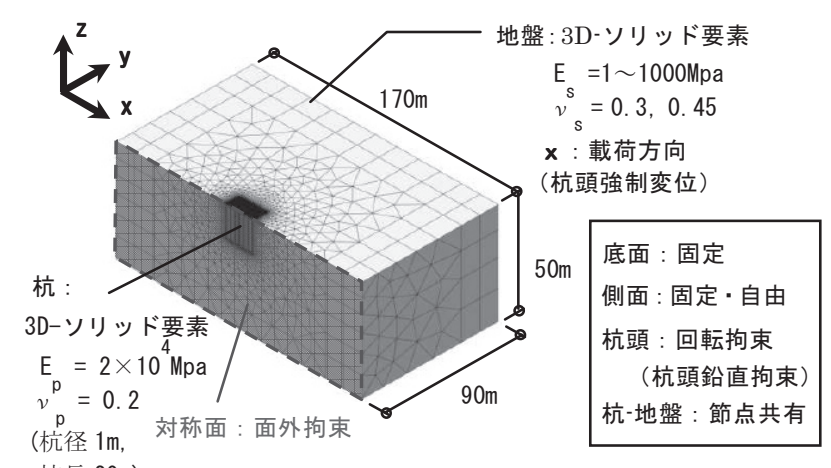

図 6 基本解析モデル

表 1 解析パラメータと回帰係数

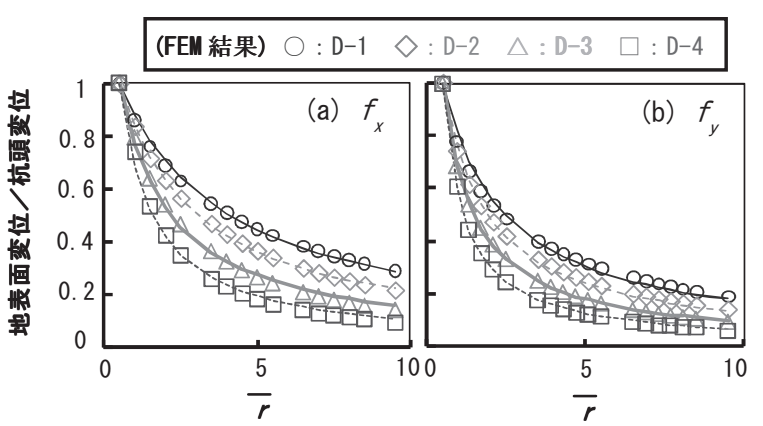

図 7 ケースD-1〜 4 地表面変位と $f_{x}, f_{y}$
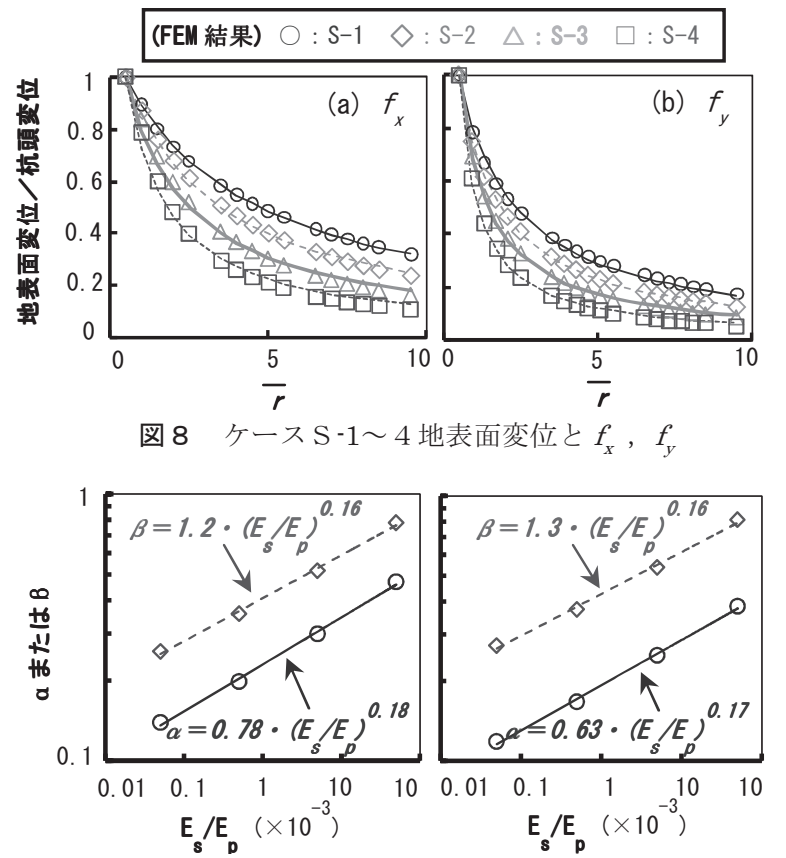

(a) ケース D-1 4 : $v_{\mathrm{s}}=0.3$ (b) ケース S-1 4: $v_{\mathrm{s}}=0.45$

図 9 地盤 /杭剛性比と図 8,9 の結果より定めた $\alpha, \beta$ の関係 
法で $a ， b, c, d$ を決定する。この結果を図 9 に示す。

図 $7 \sim 9$ より, 回帰曲線と弾性 FEM 解析結果はよく一致しており $(\bar{r} \leqq 9.5) ，(8) \sim(11)$ 式による回帰モデルが適切なことが分かる。

以上の結果より, 地盤のポアソン比 $v=0.3,0.45$ の場合の回帰 係数は表 1 のように決定できる。同表より, 地盤のポアソン比によ る回帰係数の変動は小さく,地盤のポアソン比が 0.3 から 0.45 の範 囲内では線形補間で係数を決定すれば問題ないと考えられる。

3.2 弾性 FEM 解析による弾性領域の群杭係数と提案手法の比較

提案手法による群杭係数 $e_{0}$ と図 6 の基本解析モデルにおいて多 数本の杭（杭長 $20 \mathrm{~m}$, 杭径 $1 \mathrm{~m}$, 全杭頭鉛直変位拘束）を配置し群杭 係数を求めた結果との比較を行う。群杭解析モデルの杭配置を表 2 に示す。

本検討において, FEM の群杭係数は次式により求める。

$$
\begin{aligned}
& e_{0 i}=P_{i} / P_{0} \\
& \overline{e_{0}}=\frac{\sum P_{i}}{N \cdot P_{0}}
\end{aligned}
$$

ここに, $e_{0 i}$ : 杭 $\mathrm{i}$ の群杭係数, $P_{i}$ : 杭 $\mathrm{i}$ の単位強制変位入力に対寸 る杭頭反力, $P_{0}$ : 単杭の単位強制変位入力に対寸る杭頭反力, $\bar{e}_{0}$ : 群杭全体としての群杭係数

群杭全体としての群杭係数の比較を図 10 に示す。同図より, 提 案手法は弾性領域における群杭全体としての群杭係数を良く評価で きている。

杭ごとの群杭係数の比較の例を図 $11 \sim 13$ に示す。いずれの図 においても, 提案手法は FEM と比較して定性的な傾向は一致するも のの, 外周側と中央側の杭の差はFEM よりも小さい。これは表 2 に 示した解析ケース全般で見られる傾向である。

この点の改善は今後の課題であるが，ここでは原因について検討 するため, FEM 解析結果 (ケース $\mathrm{g}-5$ ) における群杭周辺の地盤要素 地表面応力コンターを図 14 亿示寸。同図より, FEM においては地 盤の応力は群杭の外周部に集中して発生し, 群杭の内側では地盤に 発生する応力は小さい。これは群杭で囲まれる領域では杭体によっ て地盤の変形が拘束され, 杭と地盤が一体となって剛体的に挙動す ることによる。一方, 提案手法は単杭載荷の単純な重衫合わせであ るため, 同図に示されるような地盤の応力集中, 杭体による拘束効 果は評価されない。このことが提案手法において外周側と中央側の 杭の群杭係数の差が小さい原因であると考えられる。

\begin{tabular}{|c|c|c|c|c|c|}
\hline \multirow[b]{2}{*}{ 杭配列 } & \multirow[b]{2}{*}{ case } & \multicolumn{2}{|c|}{ 載荷方向 } & \multicolumn{2}{|c|}{ 直交方向 } \\
\hline & & 杭本数 & $\begin{array}{c}\text { 杭間隔 } \\
(\mathrm{m})\end{array}$ & 杭本数 & $\begin{array}{c}\text { 杭間隔 } \\
(\mathrm{m})\end{array}$ \\
\hline \multirow{5}{*}{ 直列 } & $s^{-1}$ & & 2 & \multirow{5}{*}{1} & \multirow{5}{*}{ - } \\
\hline & $s-2$ & . & 6 & & \\
\hline & $s-3$ & & 9 & & \\
\hline & $s-4$ & & 12 & & \\
\hline & $s-5$ & 5 & 3 & & \\
\hline \multirow{4}{*}{ 並列 } & $p^{-1}$ & \multirow{4}{*}{1} & \multirow{4}{*}{ - } & \multirow{3}{*}{2} & 2 \\
\hline & $p-2$ & & & & 6 \\
\hline & $p-3$ & & & & 12 \\
\hline & $p-4$ & & & 5 & 3 \\
\hline \multirow{5}{*}{ 格子 } & $\mathrm{g}-1$ & \multirow{3}{*}{3} & 3 & \multirow{3}{*}{3} & 3 \\
\hline & $\mathrm{g}-2$ & & 6 & & 6 \\
\hline & $g-3$ & & 9 & & 9 \\
\hline & $\mathrm{g}-4$ & 4 & 6 & 4 & 6 \\
\hline & $g-5$ & 7 & 3 & 7 & 3 \\
\hline
\end{tabular}

表 2 比較用 FEM モデルの群杭杭配置（杭本数 2〜 49 本）

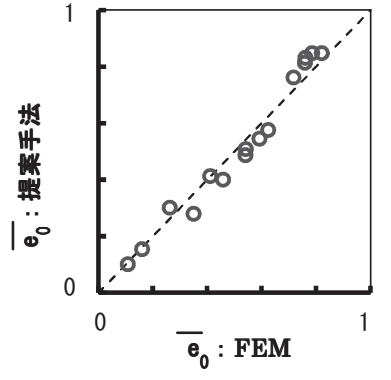

図 10 提案手法と FEM の比較 : 群杭全体の群杭係数

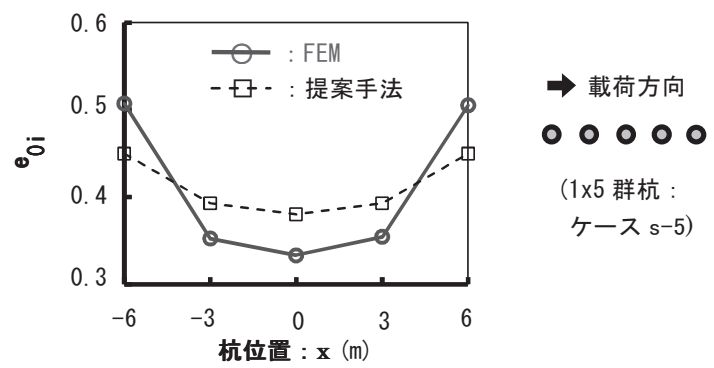

図 11 杭ごとの提案手法と FEM の比較例 1 : 直列配置

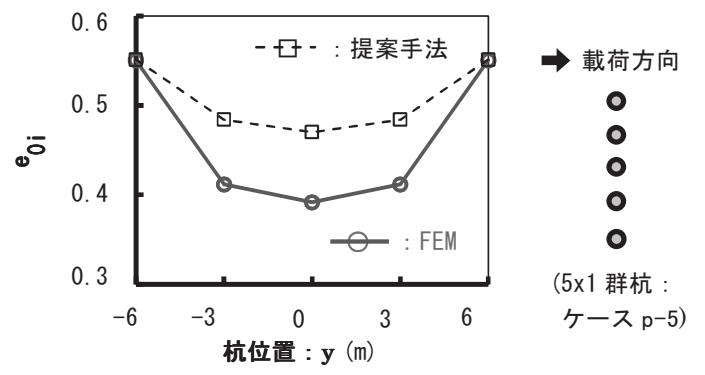

図 12 杭ごとの提案手法と FEM の比較例 2 : 並列配置
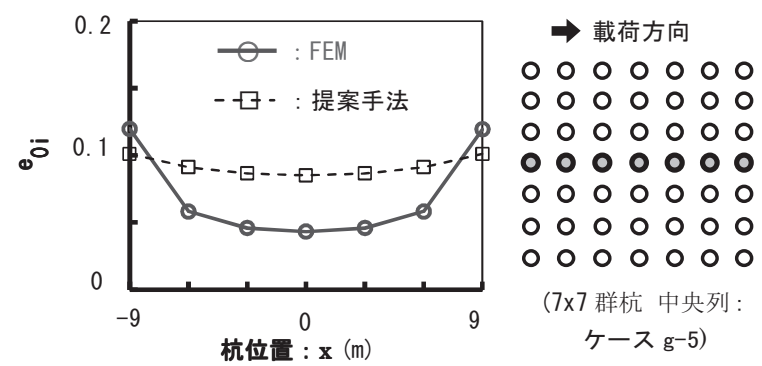

図 13 杭ごとの提案手法と FEM の比較例 3 : 格子配置

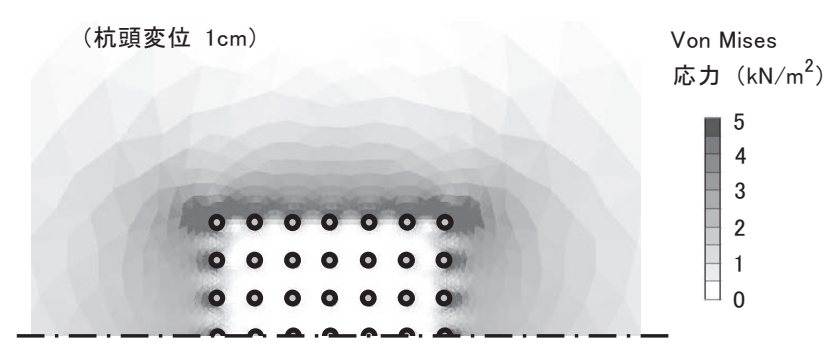

図 14 FEM 解析結果における群杭周辺の地盤要素 地表面応力コンターの例（ケース $\mathrm{g}-5$ ) 
表 3 杭長をパラメータとした FEM 解析諸元および 提案手法との適合度

\begin{tabular}{|c|c|c|c|c|c|c|}
\hline \multirow{3}{*}{ case } & \multicolumn{4}{|c|}{ 解析パラメータ } & \multirow{3}{*}{$\begin{array}{c}\text { 決定 } \\
\text { 係数 } \\
\mathrm{R}^{2}\end{array}$} & \multirow{12}{*}{ *) $\begin{aligned} v_{s} & =0.3 \\
v_{p} & =0.2\end{aligned}$} \\
\hline & \multirow{2}{*}{$\begin{array}{c}\text { 地盤 } \\
E_{\mathrm{s}} \\
(\mathrm{MPa})\end{array}$} & \multicolumn{3}{|c|}{ 杭 } & & \\
\hline & & $\begin{array}{c}\mathrm{E}_{\mathrm{p}} \\
(\mathrm{MPa})\end{array}$ & $\begin{array}{c}\text { 杭長L } \\
(\mathrm{m})\end{array}$ & $\beta L$ & & \\
\hline L2-1 & 1 & \multirow{9}{*}{20,000} & \multirow{3}{*}{2} & 0.24 & 0.73 & \\
\hline L2-2 & 10 & & & 0.45 & 0.96 & \\
\hline $\mathrm{L} 2-3$ & 100 & & & 0.83 & 1.00 & \\
\hline L5-1 & 1 & & \multirow{3}{*}{5} & 0.60 & 0.98 & \\
\hline L5-2 & 10 & & & 1.12 & 1.00 & \\
\hline L5-3 & 100 & & & 2.08 & 1.00 & \\
\hline L10-1 & 1 & & \multirow{3}{*}{10} & 1.20 & 1.00 & \\
\hline L10-2 & 10 & & & 2.23 & 1.00 & \\
\hline L10-3 & 100 & & & 4.16 & 1.00 & \\
\hline
\end{tabular}

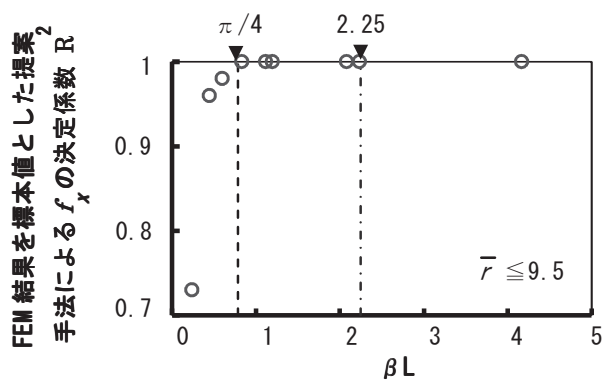

図 15 杭の $\beta \mathrm{L}$ と FEM に対する提案手法の適合度

\section{3 提案手法を適用可能な杭長の範囲}

提案手法は適用対象として十分に柔で長い杭を想定しており，こ こまでの FEM 解析は全て基本解析モデルを準用して杭長 20m（杭径 $1 \mathrm{~m})$ として行っている。本節では杭長を短くした FEM モデルによる 解析で影響係数 $f_{x}$ を算出し, 提案手法による值と比較して提案手 法の適用範囲について検討する。

FEM 解析諸元および, 解析結果を標本值とした提案手法の決定係

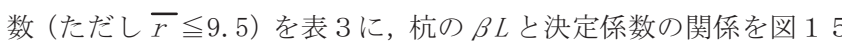
に示す。ここで $\beta$ は杭の特性值であり, $\beta=\left[k_{h} B /\left(4 E_{p} I_{p}\right)\right]^{1 / 4} . k_{h} B$ はFrancis の式 ${ }^{16)}$ を用いて計算している。同図より $\beta L>\pi / 4$ の範 囲で提案手法は FEM 結果にほぼ一致している。

図 15 の結果より, 提案手法は杭長 $L>\pi /(4 \beta)$ で適用可能だと 考えられる。余裕を見たとしても, 日本建築学会による長い杭の基 準 ${ }^{15)}$ である杭長 $L>2.25 / \beta$ あれば十分であると考えられる。

\section{4. 提案手法と実測值の比較}

既往の研究より斎藤ら 17)（文献 a), 鈴木ら 11）（文献 b）の実験 結果を引用し提案手法による結果と比較する。

文献 $\mathrm{a}, \mathrm{b}$ より定めた解析緒元を表 4 に示寸。同表において，換算 $\mathrm{E}_{\mathrm{p}}$ とは杭の曲げ剛性 $\mathrm{E}_{\mathrm{p}} \mathrm{I}_{\mathrm{p}}$ を一定として杭断面を密実断面に置き換え たときの杭の変形係数であり，解析にはこの值を用いる。

文献 $\mathrm{a}$ の実験結果における各杭の水平力負担率（ここでは各杭の 負担水平力を負担が最大となる杭の負担水平力で割った值）を提案 手法による值と比較して図 $16 ， 17$ に示す。同図より, 実測值と 提案手法はよく対応している。

文献 $\mathrm{b}$ の実験結果における各杭の水平力負担率を提案手法による 值と比較して図 18 に示す。提案手法は概敢実測值と対応した傾向 を示しているが，前面側の杭と後面側の杭の差が実測值よりもやや
表 4 既往の実験結果との比較に用いた解析緒元

\begin{tabular}{|c||c|c|}
\hline & 文献a & 文献b \\
\hline \hline $\mathrm{E}_{\mathrm{p}} \mathrm{I}_{\mathrm{p}}\left(\mathrm{kN} \cdot \mathrm{m}^{2}\right)$ & $8.9 \times 10^{3}$ & $5.0 \times 10^{-3}$ \\
\hline 換算 $\mathrm{E}_{\mathrm{p}}(\mathrm{MPa})$ & $1.8 \times 10^{4}$ & $1.6 \times 10^{3}$ \\
\hline $\mathrm{E}_{\mathrm{s}}(\mathrm{MPa})$ & 2 & 15 \\
\hline 杭配置 & $3 \times 3$ & $5 \times 5$ \\
\hline
\end{tabular}

*) 杭間隔は

両文献とも

$\bar{r}=2.5$

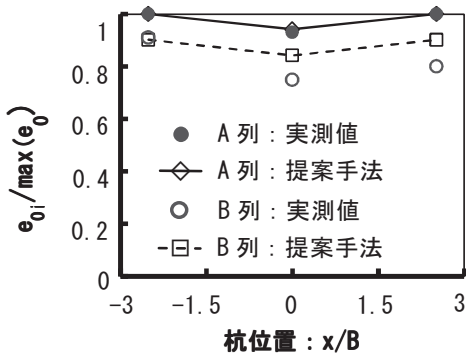

載荷方向

$($ 変位 $)=0.01 \mathrm{~B}$

- A 列

○ 0 B 列

○ 00

(3x3 群杭)

図 16 文献 $\mathrm{a}$ における静的載荷試験との比較（弾性領域）

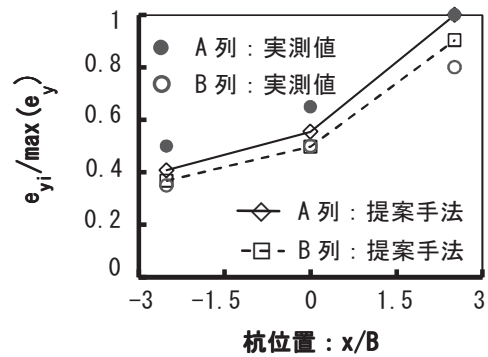

載荷方向

$($ 変位 $)=0.21 \mathrm{~B}$

- $A$ 列

$\circ \circ \circ B$ 列

○ 00

(3×3 群杭)

図 17 文献 $\mathrm{a}$ における静的載荷試験との比較（塑性領域）

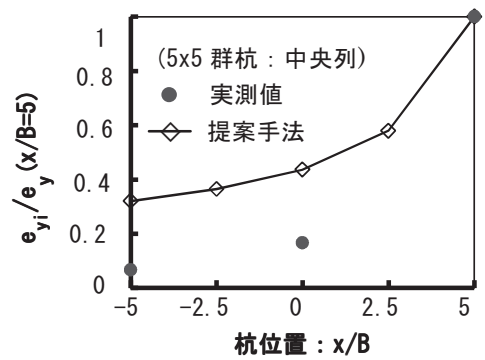

$\Rightarrow$ 載荷方向

$($ 変位 $)=0.19 \mathrm{~B}$

00000

00000

- 1 中央列

00000

00000

(5×5 群杭)

図18 文献 $\mathrm{b}$ における静的載荷試験との比較（塑性領域

小さく, 弾性 FEM の結果と比較した場合と同様，杭の位置による 違いが小さい結果となっている。

5. まとめ

杭位置の影響を考慮した群杭の非線形水平地盤ばね簡易評価手法 を提案し, 提案手法と FEM 解析結果・実験結果を比較した結果, 以下の結論を得た。

(1)提案手法を用いることにより単一の双曲線型地盤ばねで弾性領 域の群杭効果と塑性領域の群杭効果（による群杭の水平力分布）を 両方表現できる。(2)提案手法による群杭係数は群杭全体としては FEM 結果とよく整合している。(3)提案手法は定性的な傾向として は杭位置の影響を表現できているが，定量的には杭位置による負担 水平力の違いをやや過小評価寸る傾向にある。

今後は杭位置の影響をより精度よく評価するための検討を行なう。 また本検討では杭頭の回転を拘束したが，上部構造と基礎のバラン スによっては回転動が大きくなる場合も考えられる。塑性時におけ 
るアンバランスな水平力分布が転倒モーメントを発生させることも 考えられるため, 基礎（杭頭）の回転の影響についても検討する必 要がある。更にそれと並行して, 提案手法を用いた増し杭による基 礎耐震補強の設計法について検討を進める予定である。

\section{参考文献}

1) A. Wakai, S. Gose and K. Ugai : 3-D elasto-plastic finite element analyses of pile foundations subjected to lateral loading, Soil and foundations, Vol.39, No.1, pp.97-111, 1999

2）土方勝一郎, 杉山達也, 石田智昭, 伊東賢伸, 藤原一成, 橋本尚之, 酒 向裕司, 鈴木篤, 澤田祥平：3D-FEM に基づく群杭地盤ばねの非線形特性 (その 1 ) 群杭の杭頭せん断力分布, 日本建築学会大会学術講演梗概集, 構造 I , pp. 435-435， 2006

3）柏尚稔, 勝二理智, 林康裕 : 砂質地盤における杭一地盤系の強非線形を考 慮した群杭の杭頭水平地盤ば龵評価手法, 日本建築学会構造系論文集,

第 651 号，pp. 957-965，2010.5

4）金子治, 武内義夫，根本恒，平出務：杭基礎の耐震補強のための増し杭 工法に関する研究 (その 1 ) , 日本建築学会大会学術講演梗概集, 構造 I , pp.553-554, 2010

5）深田久, 加藤康司, 藤井直, 稲川浩一: 鋼矢板と固化改良を併用した既 存杭基礎の耐震補強工法の適用事例，土之基礎，56-3，pp. 18-21，2008. 3

6）冨永晃司, 山肩郁男：地盤の塑性状態を考慮した群杭の水平抵抗理論一 その 1 塑性地盤反力について一, 日本建築学会論文報告集, 第 317 号, pp. 32-40, 1982

7）冨永晃司, 山肩郁男：地盤の塑性状態を考慮した群杭の水平抵抗理論一 その 2 理論および実験結果との比較検討一, 日本建築学会論文報告集, 第 321 号, pp. 89-96，1982

8）冨永晃司, 山肩郁男 : 砂地盤中の模型群杭に関寸る水平載荷試験結果と 理論的考察，日本建築学会論文報告集，第 326 号，pp. 68-77，1983.4

9) H.G. Poulos : Behavior of laterally loaded piles: II -Pile groups, Journal of the Soil Mechanics and Foundations Division, ASCE, Vol.97, No. SM5, pp. 733-751, 1971

10) H. G. Poulos : Lateral load-deflection prediction for pile groups, Journal of the Soil Mechanics and Foundations Division, ASCE, Vol. 101, No. GT1, pp. 19-34, 1975

11）鈴木康嗣, 安達直人: 模型水平載荷試験による群杭の地盤反力〜変位関 係，日本建築学会構造系論文集，第 570 号, pp. 115-122，2003.8

12) T. Nogami : Dynamic Group Effect in Axial Responses of Grouped Piles, Journal of Geotechnical Engineering Division, ASCE, Vol. 109, No. 2, pp. 228-243, 1983

13) R. Dobry and G. Gazetas : Simple Method for Dynamic Stiffness and Damping of Floating Pile Groups, Geotechnique, Vol.38, No.4, pp. $557-574,1988$

14）土方勝一郎, 柳下文雄, 富井隆: 群杭の動的インピーダンス簡便評価法, 日本建築学会構造系論文集，第 455 号, pp. 73-82, 1994.1

15）日本建築学会：建築基礎構造設計指針，pp. 262-280，2001

16) A.J. Francis : Analysis of Pile Groups with Flexuval Resistance, Proc.ASCE, Vol.90, No.SM2, 1964

17）斎藤亮, 飯古道則, 五瀬伸吾, 易 鋒 : 杭基礎の水平方向大変形時の挙 動に関する研究，構造工学論文集，Vol. 39A, pp. 1395-1408, 1993

\section{付録＼cjkstart群杭係数の算定方法により定まる負担水平力の大小関係}

ここでは付図 1 のような単純な群杭において以下の命題 $\mathrm{A}$ が常に成り立つ ことを示す。

命題 $\mathrm{A}$ ：付図 1 のような群杭が以下の条件を満たすとき, 群杭の水平力分布 は地盤や杭の諸元によらず必ず本文図 1 の分布形を成す。

条件 1) 弾性領域の群杭係数を本文 (5) 式, 塑性領域の群杭係数を本文 (6) 式により計算する。

条件 2 ） 影響係数の評価手法が本文 (7)，（8)式の条件を満たす。
群杭係数の定義より（群杭係数） $\propto($ 負担水平力）なので, 上記の命題 $\mathrm{A}$ は以下の (付-1)，（付-2）式のように定式化できる。

$$
e_{0 B}>e_{0 F}
$$

$e_{y B}<e_{y F}$

ここに, $e_{O B}$ : 杭 B の弾性領域における群杭係数, $e_{O F}$ : 杭 $\mathrm{F}$ の弾性領域におけ る群杭係数, $e_{y B}$ : 杭 B $の$ 塑性領域における群杭係数, $e_{y F}$ : 杭 B $の$ 塑性領域に おける群杭係数

(付-1), (付-2) 式が成り立つことは直感的にも簡単に説明できる。特に 塑性領域に関して（(付-2) 式）は簡単で, 本文 (6) 式より B 杭が前方の $(m+1+1)$ 本の杭から影響を受けるのに対し F 杭の前方に位置する（=F 杭に影響を与 える）杭は 1 本のみであるので（付-2）式は明らかに成り立つ。弾性領域で は（(付-1）式), F 杭，B 杭とも他のすべての杭から影響を受けるためその点 では違いはないが, B 杭の方が群杭の端部側に位置している条件より，F杭と それ以外の杭の平均的な杭芯距離よりも $\mathrm{B}$ 杭とそれ以外の杭の平均的な杭芯 距離の方が大きくなる。したがって本文 (8)式の条件より, 平均的な影響係数 はF杭よりも B 杭の方が小さくなり, 結果(付-1)式が成り立つ。

また，数学的には以下のように（付-1），（付-2）式が成り立つことを証明 できる。まず本文 (5)，(6) 式より杭 F, 杭 B の群杭係数は以下のように表せる。

$$
\begin{aligned}
& e_{0 F}{ }^{-1}=1+\sum_{i=1}^{l} f(\Delta r \cdot i)+\sum_{i=1}^{m+k+1} f(\Delta r \cdot i) \\
& e_{y F}{ }^{-1}=1+\sum_{i=1}^{l} f(\Delta r \cdot i) \\
& e_{0 B}{ }^{-1}=1+\sum_{i=1}^{m+l+1} f(\Delta r \cdot i)+\sum_{i=1}^{k} f(\Delta r \cdot i) \\
& e_{0 B}{ }^{-1}=1+\sum_{i=1}^{m+l+1} f(\Delta r \cdot i)
\end{aligned}
$$

塑性領域（(付-2）式）については(付-4)，(付-6)式より，直ちに証明できる。

$$
\begin{aligned}
& e_{y F}{ }^{-1}-e_{y B}{ }^{-1}=\sum_{i=1}^{m+l+1} f(\Delta r \cdot i)-\sum_{i=1}^{l} f(\Delta r \cdot i)>0 \\
& \therefore e_{y B}<e_{y F}
\end{aligned}
$$

弾性領域（(付-1）式）についても, 群杭係数の逆数の差をとることで証明が 可能である。まず (付-3)，（付-5）式より

$$
\begin{aligned}
e_{0 F}{ }^{-1}-e_{0 B}{ }^{-1} & =\left[\sum_{i=1}^{l} f(\Delta r \cdot i)-\sum_{i=1}^{k} f(\Delta r \cdot i)\right]-\left[\sum_{i=1}^{m+l+1} f(\Delta r \cdot i)-\sum_{i=1}^{m+k+1} f(\Delta r \cdot i)\right] \\
& =\sum_{i=k+1}^{l-k} f(\Delta r \cdot i)-\sum_{i=m+k+2}^{l-k} f(\Delta r \cdot i)
\end{aligned}
$$

ここで $j 1:=i-k, j 2:=i-(m+k+1)$ と置けば(付-8a) 式は次式のように書ける。

$$
e_{0 F}^{-1}-e_{0 B}^{-1}=\sum_{j 1=1}^{l-k} f(\Delta r \cdot(k+j 1))-\sum_{j 2=1}^{l-k} f(\Delta r \cdot(m+k+1+j 2))
$$

(付-8b) 式はさらに整理して以下のように書ける。

$$
\begin{aligned}
& e_{0 F}^{-1}-e_{0 B}^{-1}= {[f(\Delta r \cdot(k+1))+f(\Delta r \cdot(k+2))+\cdots+f(\Delta r \cdot l)] } \\
&-[f(\Delta r \cdot(k+m+2))+f(\Delta r \cdot(k+m+3))+\cdots+f(\Delta r \cdot(m+l+1))] \\
&= {[f(\Delta r \cdot(k+1))-f(\Delta r \cdot(k+m+2))] } \\
&+[f(\Delta r \cdot(k+2))-f(\Delta r \cdot(k+m+3))] \\
&+\cdots+[f(\Delta r \cdot l)-f(\Delta r \cdot(m+l+1))] \\
&=\sum_{i=1}^{l-k}[f(\Delta r \cdot(k+i))-f(\Delta r \cdot(k+m+1+i))]
\end{aligned}
$$

(付-8c) 式において, $\Delta r \cdot(k+i)<\Delta r \cdot(k+m+l+i)$ なので本文 (8) 式の条件より， $f(\Delta r \cdot(k+i))>f(\Delta r \cdot(k+m+1+i))$ となる。したがって（付-8c）式より，

$$
\therefore e_{0 B}>e_{0 F}
$$

付図 1 均質な杭緒元を有する等間隔な群杭 